\title{
The Role of Indonesian Army Soldiers in Responding Development of Social Media
}

\author{
Dian Nur Huda, Samsul Wahidin, Sri Hartini Jatmikowati \\ University of Merdeka Malang \\ Indonesia
}

\begin{abstract}
This study aims to describe and analyze the role of TNI AD soldiers in the Information Unit of Kodam V / Brawijaya in responding to the development of social media related to their main duties and to describe and analyze the factors that support and hinder the role of TNI AD soldiers in the Information Unit of Kodam V / Brawijaya in responding to the development of social media related to its main task. The analysis technique uses a qualitative approach. The results of the analysis show that technological advances in the form of social media require special abilities for soldiers and the involvement of leaders so that the interpersonal use of social media can run optimally. The Information Unit has the role of monitoring information circulating on social media and as an effective and efficient information sharing to improve the image of the Indonesian Army in the eyes of the public. The Information Unit plays a role in assessing threat situations and making decisions to take action against threats that arise and have a serious impact on the organization. Supporting factors for the role of TNI AD Soldiers in Responding to Social Media Development in Supporting the main task of the Indonesian National Army (TNI) for the Army is the use of social media to facilitate the communication process within the unit's internal but if excessive it will affect the quality of the productivity of soldiers in the unit so that there is a control policy in the use of social media. Inhibiting factors, the use of social media is constrained by the unit leadership in monitoring its implementation as well as organizational intervention in the use of social media if it is not followed by implementation and monitoring until lower units will not run effectively.
\end{abstract}

Key Words: Role, Social Media.

\section{INTRODUCTION}

TNI as a means of state defense, functions as an deterrent against every form of military threat and armed threats from outside and within the country against the sovereignty, territorial integrity and safety of the nation, Acting against every form of threat as referred to in paragraph (1) letter a, and restoration against the state's security condition which was disturbed due to security chaos None of the laws that exist at this time, neither the law on the TNI, Polri, nor the Law on Defense directly discuss the meaning of "National Security". Even though there are some overlaps (gray areas), however in fact it does not in the least diminish the meaning of the duties and roles of both the TNI and Polri. In the discussion of Law No.2 of 2002 and Law No.34 of 2004,

The role of TNI AD soldiers as mandated in Law Number 34 of 2004 concerning the TNI, where the Main Task of the TNI is to uphold state sovereignty, maintain the territorial integrity of the Unitary State of the Republic of Indonesia and the safety of the entire nation from military threats and non-military threats. The task of the TNI is one of the efforts to achieve the national goals as stated in the preamble to the 1945 Constitution, namely protecting the entire nation and all spilled Indonesian blood. Therefore, to be able to answer the tasks that are the responsibility of the TNI AD,

The sophistication and development of internet technology, in this regard to the development of information media, is currently experiencing a sharp increase, making all information originating from within and outside the country easily accessible to all people from various circles. Now, we not only see news from television, radio, newspapers, magazines and films, we can search and update information from the internet. We want to search for anything on the internet that has been presented, how extraordinary the internet can help provide good and bad information even though there is one there.

TNI soldiers as the main elements in the defense sector should have an important role in responding to the developments that occur on social media. Role is the behavior expected of someone who has a status. Each person may have a number of statuses 
and is expected to fill the role corresponding to that status. In a sense, status and role are two aspects of the same phenomenon. Status is a set of rights and obligations and role is the role of the set of obligations and rights (Horton, 1999: 118).

The role of a soldier in responding to social media developments is a dynamic aspect of his position (status) as a defense guard. When a person exercises his rights and obligations in accordance with his position, he plays a role. The distinction between position and role is for the benefit of science. The two cannot be separated, because one is dependent on the other and vice versa. There is no role without position or position without role. As with position, role has two meanings. Each person has various roles that come from the patterns of his life. This at the same time means the role that the role determines what he does for the community and what opportunities the community gives him. The importance of a role is that it regulates a person's behavior. The role of causing a person to a certain extent can predict the actions of others. The person concerned will be able to adapt his own behavior to the behavior of his group of people. Social relations that exist in society are the relationships between individual roles in society. Roles are governed by prevailing norms. For example, the norm of modesty requires that a man, when walking with a woman, be outside. Likewise with the role of a soldier in responding to the development of social media which must also aim to cement the unity and defense of this nation. The person concerned will be able to adapt his own behavior to the behavior of his group of people. Social relations that exist in society are the relationships between individual roles in society. Roles are governed by prevailing norms. For example, the norm of modesty requires that a man, when walking with a woman, be outside. Likewise with the role of a soldier in responding to the development of social media which must also aim to cement the unity and defense of this nation. The person concerned will be able to adapt his own behavior to the behavior of his group of people. Social relations that exist in society are the relationships between individual roles in society. Roles are governed by prevailing norms. For example, the norm of modesty requires that a man, when walking with a woman, be outside. Likewise with the role of a soldier in responding to the development of social media which must also aim to cement the unity and defense of this nation. the norm of modesty requires that a man when walking with a woman should be outside. Likewise with the role of a soldier in responding to the development of social media which must also aim to cement the unity and defense of this nation. the norm of modesty requires that a man when walking with a woman should be outside. Likewise with the role of a soldier in responding to the development of social media which should also aim to cement the unity and defense of this nation.

Basically, the role of soldiers in responding to the development of social media can be analogous to the position of actors in theater (play). As in theater, the position of people in society is the same as that of actors in theater, namely that the behavior expected of them does not stand alone, but is always in relation to the existence of other people who are related to the existence of other people associated with the actor. From this point of view, role theories are compiled (Sarwono, 1995: 209).

If what is meant by role is the behavior expected of someone in a certain status, then role behavior is the actual behavior of those who perform that role. Role behavior may differ from the expected behavior for several reasons. A person may not perceive a role in the same way as others see it, a person's personality traits affect how that person perceives the role, and not everyone filling a role feels as attached to the role as this can conflict with other roles. All these factors are integrated in such a way that no two individuals play a particular role in exactly the same way. Not all warriors are brave, not all priests are holy, not all professors have scientific achievements. Quite a lot of differences in role behavior that cause variations in human life. However, there is sufficient uniformity and predictability in role behavior to carry out an orderly social life.

\section{LITERATURE REVIEW}

\subsection{Role Theory}

Role theory defines "role" or "role" as the boundaries and sets of expectations applied to role incumbents of a particular position, which are determined by the role incumbent and role senders within and beyond the organization's baoundaries "(Banton, 1965; Katz \& Kahn, 1966, in Bauer, 2003: 54). In addition, Robbins (2001: 227) defines role as "a set of expected behavior patterns attributed to someone occupying a given position in a social unit".

According to Dougherty \& Pritchard (1985) in Bauer (2003: 55), this role theory provides a conceptual framework in the study of behavior in organizations. They claim that the role "involves a pattern of product creation as opposed to behavior or action". Furthermore, Dougherty \& Pritchard (1985) in Bauer (2003: 56) argues that the relevance of a role will depend on the emphasis of the role by evaluators and observers (usually supervisors and leaders) on the product or outcome produced. In this case, strategy and organizational structure are also proven to influence role and role perception (Kahn, et.al., 1964; Oswald, Mossholder, \& Harris 1997 in Bauer, 2003: 58). 


\subsection{Social Communication Theory}

Social communication, the definition of communication in terms of communication in a general sense. Social communication in general is everyone who lives in and society, from waking up to sleeping again, by nature is always involved in communication. Society consists of at least two people who are related to each other and the relationship creates social interaction.

According to Santoso (2006) social communication is a social unit consisting of two or more individuals who have had sufficiently intensive and regular social interactions, so that among those individuals there is already a division of tasks, structures, and certain norms.

\subsection{Information Technology and Social Media}

Information technology as a set of tools that help you work with information and perform tasks related to information processing. Information technology is not only limited to computer technology (hardware and software) used to process and store information, but also includes communication technology that transmits information. Meanwhile, Williams and Sawyer (2003) define information technology as a technology that combines computing (computers) with high-speed communication lines that carry data, voice and video. William and Sawyer (2005) complete the definition of information technology as a general form that describes any technology that helps generate, manipulate, store, communicate, and convey information. From the definition above, we can see some similarities in definition. Therefore, it can be concluded that what is meant by information and communication technology is all technology, including a combination of computer technology and telecommunications technology that can help humans to produce, manipulate, store, communicate, and convey information.

The presence of the media with all its advantages has become a part of human life. The times have produced various media, one of which is social media. Social media is a medium on the internet that allows users to represent themselves and interact, cooperate, share, communicate with other users, and form virtual social bonds. Social media is a digital media where social reality occurs and the space-time of its users interacts. The values that exist in society and the community can also appear in the same or different forms on the internet. Basically, some experts who research the internet see that social media on the internet is a picture of what is happening in the real world, such as plagiarism (Nasrullah, 2016).

\subsection{Theory of Social Change}

Social change is a change in the social order of life which includes: changes in social values and norms, patterns of individual and organizational behavior, composition of social institutions, social strata or class, power and authority. Thus, social change will create differences from the previous one, resulting in a condition in the social structure that is not functionally compatible.

According to Davis (1960: 112), social change is part of cultural change. Cultural change includes universal cultural elements, while social change includes changes in social structures. The relationship between social change and cultural change is based on the perspective that cultural changes that arise and affect social organization can result in disruption of social balance. If the social balance is disturbed, it will cause changes in the social structure.

\subsection{Social Interaction Theory}

Interaction comes from English Interaction, which means influencing each other or all things influence. Prof Soerjono Soekamto's (1983) rich sociology dictionary gives an understanding of interaction is a reciprocal relationship between certain parties. While the meaning of the word social refers to interpersonal actors or those related to social processes. So social interaction is a dynamic reciprocal relationship between individuals (inter-personal), between human groups and between individuals and groups. In other words, social interaction implies a process in which people who communicate influence each other in terms of feelings, thoughts, and actions. Social interaction is one of the most basic things in life. Because social interaction is the basis of social processes. Social processes are ways of relating that can be seen when individuals and groups of people meet each other and determine the systems and forms of these relationships. Social processes are defined as the mutual influence between the various arts of living together. Social interaction begins when two people meet and then confront each other, shake hands and then talk at length. Social interaction also occurs when a protocol person in an event greets the entire audience. Social processes are ways of relating that can be seen when individuals and groups of people meet each other and determine the systems and forms of these relationships. Social processes are defined as the reciprocal influence between the various arts of living together. Social interaction begins when two people meet and then confront each other, shake hands and then talk at length. Social interaction also occurs when a protocol person in an event greets the entire audience. Social processes are ways of relating that can be seen when individuals and groups of people meet each other and determine the systems and forms of these relationships. Social processes are defined as the reciprocal influence between the various arts of living together. Social interaction begins when two people meet and then confront each other, shake hands and then talk at length. 


\subsection{The Theory of Military Sociology}

In the history of its development, sociology has established multidimensional and multilevel relationships with other disciplines. For example, the relationship between sociology and various different disciplines. Sociology, in this context, can be said to be one of the most open disciplines to other disciplines. This openness can be seen in the many sources of citations in various academic publications. Therefore, considering that the study of sociology is essentially interdisciplinary (crossdisciplinary), in order to provide a more comprehensive basis of viewpoint for the core study of this book, we need to briefly review institutional theory, political sociology and military sociology, in which the three actually has a very close relationship because in fact the military and political phenomena are on a bigger stage;

\section{LITERATURE REVIEW}

\subsection{Research Approach and Strategy}

An approach is a way of approaching something so that the rich culture as a meaning structure can be clearly expressed. Other terms that are considered to have parallels with other approaches: approach, perspective, point of departure, dimensions and glasses. The approach is the treatment of objects as an ethical point of view or vice versa as an emic point of view (Moleong, 2012).

In a qualitative approach, there are several forms of research that differ from one another in direction, goals, interests, and final results. In a qualitative approach, there is a form of research that is not only adapted to the type of data and the research objectives, but also in terms of the paradigm of thinking, problem approach, problem definition, research questions, and research use and results. Qualitative research forms are also called qualitative research models (Herdiansyah, 2012).

\subsection{Research Focus}

Based on the description of the background of the problem and the formulation of the problem, the focus of the research is as follows:

1) The Role of Indonesian Army Soldiers Responding to the Development of Social Media in Supporting the main duties of the Indonesian National Army (TNI) of the Army with the indicators:

a. Interpersonal Roles in Utilizing Social Media

b. Informational Role in Utilizing Social Media

c. The Role of Decision Making

2) Supporting and inhibiting factors, with indicators:

a. Supporting factors:

(1) Internal factors: Soldier Communication Process

(2) External factors: Organizational policies

b. Obstacle factor

(1) Internal Factors: Position and rank

(2) External Factors: Intervention from the organization

\subsection{Data analysis technique}

Qualitative data analysis according to Bogdan and Biklen (Miles and Hubberman, 2014: 14) is an effort made by working with data organizing data, sorting it into manageable units, synthesizing it looking for and finding patterns, finding what is important and what is learned and decide what to tell others. Data were analyzed using several steps according to the theory of Miles, Huberman and Saldana (2014), namely analyzing data in three steps: data condensation, display data, and conclusion drawing and verification.

\section{DISCUSSION}

4.1 The Role of Indonesian Army Soldiers Responding to the Development of Social Media in Supporting the Main Duties of the Indonesian National Army (TNI) Army in the Information Unit

The main role of the information unit of Kodam V / Brawijaya, is to convey information correctly and professionally about the matters of the TNI AD as a state defense force to the public, and to provide sympathetic responses when there is information that 
is considered to be detrimental to the positive image of the Army. Apart from that, as an institution that is also an "Information Agent", it is tasked with processing information, conveying information, managing information, both for internal and external parties, and all of this is aimed at supporting the main duties of the Indonesian Army.

In this context, addressing the development of social media, the role of the Military Command V / Brawijaya Information Unit in anticipating the emergence of news from social media cornering the Army, it is very important to minimize the bad effects and improve the image of the TNI AD, as conveyed by Dugherty \& Pritchard (1985), stated that the role provides a conceptual framework for the study of behavior and organization. Besides, the relevance of a role that will depend on the emphasis of the role by the assessors and observers. The role of the Kodam V / Brawijaya Information Unit is a pillar of the success of achieving its goals as a leader in various fields of information, one of which is news and dissemination of information through social media, therefore the role of the Information Unit of Kodam V / Brawijaya, In realizing its main duties and functions, it is very important, especially the Interpersonal Role in the Utilization of Social Media, the Informational Role in Utilizing Social Media, and the role as a decision maker in information organizations. In terms of organizational behavior, the role is one of the components of the social system of the organization, in addition to organizational norms and culture.

From the role of an Information Unit of Kodam V / Brawijaya, it is hoped that this will increase the understanding of Indonesian Army (TNI) soldiers in responding to existing social media developments. Stephen Robins (2001: 227) states that the role is as "a set of expected thatour patterns attributed to Some One occupying a given position in a social unit", namely behavior patterns associated with someone occupying a certain position in social organizations. In this study, there are several roles in the information unit soldiers in responding to social media, including interpersonal and informational roles and decision making in the development of social media.

\subsubsection{Interpersonal Roles in Utilizing Social Media}

The role of an interpersonal nature is one of the demands that must be met by a manager, namely human skills. This skill is absolutely necessary because basically in carrying out his leadership, a manager interacts with other humans, not only with his subordinates, but also various interested parties known as stake holders, inside and outside the organization. Related to this research are the skills and abilities of the judges in the Kodam V / Brawijaya information unit related to their role in responding to the development of social media as a means to facilitate the dissemination of information which is their field of duty.

The results show that the advancement of information technology has an impact on changing the habit of communicating using social media, this also has an impact on changing the paradigm of defense threats which are the main duties of a soldier. In responding to this, a soldier must be wise in responding to the development of social media as a means of delivering information, besides that the role of TNI AD personnel and families is expected to be wiser in responding to and using social media and it is not easy to spread it before filtering it first. Where this requires the ability to be able to control and limit yourself in activities in response to social media developments.

\subsubsection{Informational Role in Utilizing Social Media}

The role of informational use in the use of social media is very much needed considering that currently the delivery of information using social media is a critical organizational asset to support the main task of soldiers in maintaining the integrity of the Republic of Indonesia where this will be carried out efficiently and effectively with the support of up-to-date, complete, information. and can be trusted. In carrying out this informational role requires a soldier to always monitor the flow of information that occurs from and into the TNI organization, besides that the soldiers in responding to this social media development must also be able to act as information sharing.

The results showed that the informational role in the form of monitoring information circulating on social media, especially the TNI army information unit, has shown that the personnel of the Information Unit of the Military Command V / Brawijaya have monitored information circulating on social media, especially those related to news about TNI institutions either sourced from unit institutions, soldiers personally and in the community by always monitoring the circulating news which is then made a routine report from there will be monitored news related to the TNI AD institution and where the news sources come from. This monitoring or monitoring is carried out to conduct an opinion on fake news (hoax) within the TNI AD in the Information Unit which has a role as information sharing.

Furthermore, the Information Unit as an information provider has distributed information appropriately and efficiently to those in need, in its implementation it can be accessed by the public directly through the website we provide atwww.kodam5brawijaya.mil.id as well as in other social media platforms such as Twitter, Instagram and Facebook which are managed by the Kodam V / Brawijaya Information Unit. 


\subsubsection{Role in decision making}

The role of decision making referred to in this study is the role of a soldier in responding to the development of social media, which is expected to be able to continuously study the situation faced by the organization, to seek and find opportunities that can be exploited in relation to threats that may arise. Furthermore, the role in reducing disturbances is manifested by the willingness to take responsibility for making corrective action decisions if the organization and society will face serious disturbances which if not handled will have a negative impact on the TNI itself and for national defense.

Decision making related to attitudes towards the development of social media, especially in analyzing or conducting studies related to whether or not news circulating on social media is in line with Mintzberg's opinion, concluding that the leader / manager in this case is a unit of information that in essence most of his duties are used fully for think about the system for making organizational strategies. Leaders are substantially involved in every organizational decision-making. This involvement is due to: (1) the formal authority of the manager is the only one who is allowed to be involved in thinking about important or new actions in the organization; (2) as an information center, managers / leaders can guarantee the best decisions, reflecting the latest knowledge and values of the organization; (3) strategic decisions will be easier to take in an integrated manner with one person who can exercise control over everything (Thoha, 2004: 271).

The results also show the role of the Information Unit decision-making in responding to the development of social media, which must then be followed by the ability to maximize existing opportunities in order to minimize the threat posed by implementing a counter-opinion strategy by forming new opinions from the public on news that is divisive in society. The ability to maximize opportunities in decision making is also in line with the opinion of Ralp C. Davis, (1999) that defines decisions as the result of resolving the problems faced firmly. A decision is a definite answer to a question. The decision must be able to answer questions about something that is discussed in connection with planning.

\subsection{Supporting and Inhibiting Factors}

\subsubsection{Supporting Factors}

Ease in the process of easy interaction and communication in order to support the performance of organizational units by utilizing social media in the Pendam V / Brawijaya organizational unit, this is indicated by the results of research which show that the use of social media on various platforms makes it easier for personnel to communicate and interact quickly regarding activities that are will be implemented. This shows that social media is a means of social communication for information units in line with the opinion.According to Santoso (2006) social communication is a social unit consisting of two or more individuals who have had sufficiently intensive and regular social interaction, so that there are already division of tasks, structure, and certain norms.

Regarding the use of social media which is very useful in building communication between personnel members in the information unit in order to make it easier for them to carry out their activities and tasks, this is as stated by Shirky (2008), which explains that social media and social software are tools to increase the user's ability to share, to co-operate) among users and take collective action, all of which are outside the institutional and organizational framework.

The use of social media, which is considered as a means of supporting communication, cannot be denied that the development of social media has had a considerable influence, and social media currently plays an important role in all soldier's activities. This is in line with Rahmani (2016: 22), the use of media by individuals can be seen from three things, namely: The amount of time, this is related to the frequency, intensity, and duration used in accessing social media, media content, namely choosing media and methods. appropriate so that the message to be conveyed can be communicated properly and media relations with individuals in this study are the relationship between users and social media.

Human-computer interaction is a concept that explains the relationship between humans and computers not only in a narrow scope but also in a more universal range. This concept describes the processes, dialogues, and activities through which users make use of and interact with computers. Human interaction with media can be categorized under this concept. Humans who cannot be separated from information always take advantage of communication technology based on computer technology in their lives. When this interaction occurs, there will also be impacts generated by the media from various existing perspectives. This humancomputer interaction is an intermediary for the implications of changing human behavior and attitudes in the communication process.

The results also show that there are soldiers who use them excessively which can have an impact on their actual field of work, because it cannot be denied that the negative influence of social media affects the productivity quality of soldiers in units, this is in line with the opinion that although technology provides many benefits to humans, but on the other hand, technological progress 
will have a negative effect on the socio-cultural aspects as well as the changing patterns of human interaction due to the presence of computers and cell phones (Ngafifi, 2014).

The results of the study also show that the existence of a policy in the use of social media is one of the controls for TNI AD institutional personnel to use social media, there are several events / incidents that arise as a result of misuse of social media among soldiers and their families as a result of ignoring the policies made. In general, social media has a positive impact on the TNI and its families, namely providing a wide, fast communication media and network, gaining insight and self-development to adapt and socialize, but on the other hand, social media has a negative impact on soldiers due to ignoring policies that have been implemented. institutionalized.

\subsubsection{Obstacle Factor}

Internal inhibiting factors in the form of positions and ranks related to the hierarchy contained in the TNI institution find that a leader can perceive that by using social media he will get a wide, fast command network, gain insight and self-development to adapt and socialize with its members. But the phenomenon is that the unit leader does not care about the use of social media by his soldiers, even though an officer has a big responsibility towards his subordinates as a leader.

This is in line with organizational communication, which is the sending and receiving of various organizational messages in formal and informal groups of an organization (Wiryanto, 2005). Formal communication is communication that is agreed upon by the organization itself and is oriented towards the interests of the organization. The contents are in the form of ways of working within the organization, productivity, and various jobs that must be done within the organization. For example: memos, policies, statements, press conferences, and official letters. The informal communication is communication that is socially approved. The orientation is not on the organization, but rather on its individual members.

The need for a leader's role in the communication process using social media is an organizational communication process where the correlation between communication science and the organization lies in a focused review of the humans involved in achieving the organizational goals. Communication science questions what forms of communication take place in an organization, what methods and techniques are used, what media are used, how the process is, what factors become obstacles, and so on. The answers to these questions are for study material to further present a conception of communication for a particular organization based on the type of organization, the nature of the organization, and the scope of the organization taking into account the particular situation at the time the communication was launched.

Sendjaja (1994) states that communication functions in organizations are as follows: 1) Informative functions. Organization can be viewed as an information processing system. That is, all members in an organization hope to get more, better and timely information. The information obtained allows each member of the organization to carry out their work with more certainty. People at the management level need information to make an organizational policy or to resolve conflicts that occur within the organization. While employees (subordinates) need information to carry out work 2) Regulatory function. This function is related to the regulations that apply in an organization. There are two things that affect the regulative function, namely: a. With regard to people who are at the management level, namely those who have the authority to control all information conveyed. Also giving orders or instructions so that the orders are carried out properly. b. With regards to messages. Regulative messages are basically work-oriented. This means that subordinates need certainty about what work can and shouldn't be done. 3) Persuasive function. In regulating an organization, power and authority will not always bring the expected results. Due to this fact, many leaders prefer to persuade their subordinates rather than giving orders. Because work that is done voluntarily by employees will generate greater concern than if the leadership often shows their power and authority. 4) Integrative function. Every organization strives to provide a channel that allows employees to carry out their duties and jobs properly. There are two communication channels that can make this happen, namely: a. Formal communication channels such as specific publications within the organization (newsletters, newsletters) and organizational progress reports. b. Informal channels of communication such as interpersonal conversations during work breaks, sports competitions or excursions. The implementation of this activity will foster a desire for greater participation by employees in the organization.

The next external inhibiting factor is organizational intervention in addressing the development of social media among soldiers, the results of the research show that intervention in the form of policies will not work if it is not monitoring to the lowest unit, this shows that the intervention from the TNI AD organization is only in the form of policies on how to socialize for a soldier. This of course will not run effectively without being implemented and monitored directly by the organization. The development of information and communication technology has brought society into a new civilization, namely the digital society. 


\section{CONCLUSIONS AND SUGGESTIONS}

\subsection{Conclusion}

From the description above it can be concluded that:

1) Technological advances in the form of social media require special skills for soldiers and the involvement of the leaders so that the interpersonal use of social media can run optimally.

2) The Information Unit has the role of monitoring information circulating on social media as well as an effective and efficient information sharing to improve the image of the Indonesian Army in the eyes of the public

3) The Information Unit plays a role in assessing threat situations and making decisions to take action against threats that arise and have a serious impact on the organization.

4) Supporting and driving factors The Role of Indonesian Army Soldiers Responding to Social Media Developments in Supporting the Main Duties of the Indonesian National Army (TNI) of the Army include:

a. Supporters

The use of social media simplifies the internal communication process in the unit, but if it is excessive, it will affect the productivity quality of soldiers in the unit so there is a control policy in the use of social media

b. Blockers

The use of social media is constrained by the unit leadership in monitoring its implementation and organizational intervention in the use of social media if it is not followed by implementation and monitoring until the lower units are not will be effective

From the results of these findings, a Major Proposition can be drawn up. The role of the judges in the information unit in responding to technological advances in the form of social media requires special abilities to play a role in monitoring information, as information sharing, the process of assessing threat situations and making decisions to take action.n against the threats that arise.

\subsection{Research Recommendations}

After analyzing the phenomena shown by the Role of Army Soldiers in Responding to Social Media Developments in Supporting the Main Duties of the Indonesian National Army (TNI) for the Army, it is necessary to recommend a number of things that need to be recommended as constructive suggestions as follows.

\subsubsection{Theoretical Implications}

In this study, it examines the problem of the Role of Indonesian Army Soldiers in Responding to the Development of Social Media in Supporting the Main Duties of the Indonesian Army (TNI) of the Army with the main theory (grand theory), namely the theory of the role of Scotetal (1981) and Kanfer (1987: 197) mentioning important aspects. of the role, namely: The role is impersonal: and the position of the role will determine expectations, not the individual. Roles are related to work behavior, namely the expected behavior in a particular job, the role is difficult to control, the role can be learned quickly and can result in major behavior changes. Roles and jobs are not the same, someone who does one job may play several roles,

\subsubsection{Practical Implications}

In accordance with the results of the research findings, there are several suggestions that can be practical contributions to this research, namely as follows:

1) In anticipating technological advances, especially regarding the use of social media in their communication, they should improve the communication skills of soldiers to the lower unit level

2) To minimize the existence of information circulating in society that is cornering the TNI, it should intensify the use of social media in all units and pay attention to the continuity of the media used.

3) The TNI commando organization should not only make a policy on how a soldier uses social media but also monitor it down to the lowest level of the implementation of the policy.

\section{REFERENCES}

Bauer, Jeffrey C. (2003). Role Ambiguity and Role Clarity: A Comparison of Attitudes in Germany and the United States. Dissertation, University of Cincinnati - Clermont.

Davis, Kingsley, (1960). Human Society. The Mac Millan Company : Newyork

Herdiansyah, Haris. (2012). Metodologi Penelitian Kualitatif Untuk Ilmu-Ilmu. Sosial. Jakarta Selatan: Salemba Humanika..

Horton, B.P. dan Chester L. Hunt. 1999. Sosiologi. Jakarta: Erlangga. 
International Journal of Research in Social Science and Humanities (IJRSS), Vol .1(5), Nov-Dec - 2020

Miles, M.B, Huberman, A.M, dan Saldana, J. 2014.Qualitative Data Analysis, A. Methods Sourcebook Edition 3.

Moleong, Lexy J. (2012). Metodologi Penelitian Kualitatif. Bandung

Nasrullah, Rulli. (2016). Media Sosial:Perspektif Komunikasi, Budaya, dan Sosioteknologi. Bandung:Simbiosa Rekatama Media.

Ngafifi, Muhammad. 2014. Kemajuan teknologi dan pola hidup manusia dalam prespektif social budaya. Jurnal perkembangan pendidikan: fondasi dan aplikasi. Vol 2 No. 1: 34-35

Rahmani. (2016). Komunikasi Antarbudaya (Di Era Budaya Siber). Jakarta:Prenada Media Group.

Robbins, Stephen P. (2001). Organizational Behavior, 9 ed.. Upper Saddle River, New Jersey, 07458: Prentice-Hall Inc.

Rochaety, Eti. (2005). Sistem Informamsi Manajemen Pendidikan. Jakarta : Bumi Aksara.

Santoso, Sastropoetro. (2006). Pendapat Publik, Pendapat Umum, dan Pendapat Khalayak dalam Komunikasi Sosial. Bandung: Remaja Rosdakarya,

Sarwono, Sarlito (1995). Psikologi Lingkungan. Jakarta : Grasindo

Sendjaja, S. Djuarsa. 1994. Teori Komunikasi. Jakarta: Universitas Terbuka

Soekanto, S. (2006). Sosiologi Suatu pengantar. Jakarta: PT Raja Grafindo Persada.

Soekanto, Soerjono. 1983. Teori Sosiologi tentang Perubahan sosial. Surabaya : Ghalia Indonesia.

Thoha, Miftah. (2004). Perilaku Organisasi, Konsep Dasar dan Aplikasinya. Jakarta: Raja Grafindo Persada.

Williams and Sawyer. (2003). Using Information Technology: A Practical Introduction to Computers and Communications. London: Career Education.

Wiryanto. (2005). Pengantar Ilmu Komunikasi. Jakarta. PT. Grasindo. 